\title{
Evolving the Nation's Energy Infrastructure: A Challenging System Issue for the Twenty-First Century
}

Conference Paper NREL/CP-600-41404 April 2007

\section{Preprint}

B. Garrett

To be presented at the International Conference on System of Systems Engineering San Antonio, Texas

April 16-18, 2007

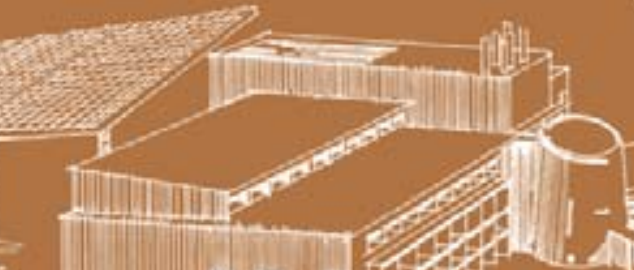




\section{NOTICE}

The submitted manuscript has been offered by an employee of the Midwest Research Institute (MRI), a contractor of the US Government under Contract No. DE-AC36-99G010337. Accordingly, the US Government and MRI retain a nonexclusive royalty-free license to publish or reproduce the published form of this contribution, or allow others to do so, for US Government purposes.

This report was prepared as an account of work sponsored by an agency of the United States government. Neither the United States government nor any agency thereof, nor any of their employees, makes any warranty, express or implied, or assumes any legal liability or responsibility for the accuracy, completeness, or usefulness of any information, apparatus, product, or process disclosed, or represents that its use would not infringe privately owned rights. Reference herein to any specific commercial product, process, or service by trade name, trademark, manufacturer, or otherwise does not necessarily constitute or imply its endorsement, recommendation, or favoring by the United States government or any agency thereof. The views and opinions of authors expressed herein do not necessarily state or reflect those of the United States government or any agency thereof.

Available electronically at http://www.osti.gov/bridge

Available for a processing fee to U.S. Department of Energy and its contractors, in paper, from:

U.S. Department of Energy

Office of Scientific and Technical Information

P.O. Box 62

Oak Ridge, TN 37831-0062

phone: 865.576 .8401

fax: 865.576 .5728

email: mailto:reports@adonis.osti.gov

Available for sale to the public, in paper, from:

U.S. Department of Commerce

National Technical Information Service

5285 Port Royal Road

Springfield, VA 22161

phone: 800.553 .6847

fax: 703.605.6900

email: orders@ntis.fedworld.gov

online ordering: http://www.ntis.gov/ordering.htm 


\title{
Evolving the Nation's Energy Infrastructure: A Challenging System Issue for the Twenty-First Century
}

\author{
Bobi A. Garrett \\ Associate Director \\ National Renewable Energy Laboratory \\ Golden, CO 80401 \\ bobi_garrett@nrel.gov
}

Over the next several decades, a profound transformation of the global energy enterprise will occur driven largely by population growth and economic development. How this growing demand for energy is met poses one of the most complex and challenging issues of our time. The current national energy dialogue reflects the challenge in simultaneously considering the social, political, economic, and technical issues as the energy system is defined, technical targets are established, and programs and investments are implemented to meet those technical targets.

\section{Introduction}

The Energy Information Administration forecasts that global demand for energy will grow more than $70 \%$ between the baseline year 2003 and 2030 [1]. Most of this growth will occur in the developing world (Figure 1), driven both by population growth and by the realization of economic development aspirations. In the U.S., concerns with energy security and increasingly the global environment will shape the evolution of the Nation's energy infrastructure as it grows to accommodate an increase in demand of nearly $30 \%$ over the next 25 years.

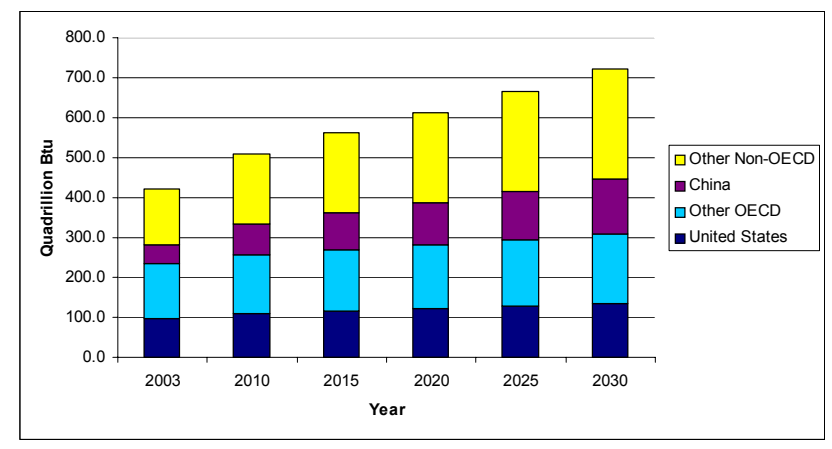

Figure 1. Global Energy Consumption Projections

The nation's energy system, comprising systems to extract, convert, deliver, and use energy (Figure 2), operates within a dynamic and highly interrelated context. This context is also comprised of systems that include among others, the ecological, economic, political, and social systems. The

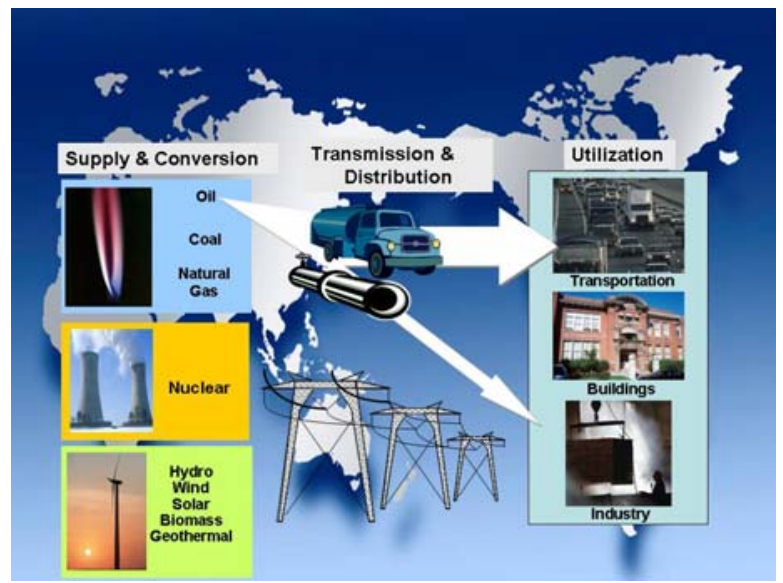

Figure 2. Major Energy System Elements

complexity of this 'system of systems' and the dynamics of the environment within which it operates pose challenges for reaching consensus on the both a concept of operations and specific technical targets required to create an energy system that is more secure, reliable, environmentally responsible, and supportive of a thriving economy.

The recent battle waged in Texas that led to the decision by TRU Corporation to cancel its plans to construct eight of 11 planned coal-fired power plants illustrates the complexity of the interactions between the physical energy system and the socio-political systems within which it operates. In this case, the debate involved trade offs between environmental and economic interests. Environmentalists raised concerns regarding air emissions that could impact the global and local environment and local businesses were concerned that a reduction in air quality could potentially trigger additional Federal clean air regulation that would impact their economic interests. On the other side of the debate were local communities and railroad companies that would benefit economically from new plant construction. In addition to the cancellation of coal plants, ultimately the approval of the acquisition of TXU by an investor group also required commitments to increase renewable energy, implement a demand reduction program, and to reduce mercury and $\mathrm{CO}_{2}$ emissions, among other concessions [2]. 
Fully understanding the implications of energy technology investment options requires understanding:

- The potential impact of technology options on the energy system from supply through end use, both from a point-of-use and a life cycle perspective.

- The potential impacts of changes in the energy system on the operating environment (natural, economic, political, and social systems).

- The potential impact of changes in the operating environment on the system requirements.

Limiting the scope of technology evaluations to their point of generation or use may obscure the full impact of a technology decision. This can be simply illustrated by comparing the carbon emissions on a point-of-release basis with carbon emissions from an overall system perspective. In either case, the electric power sector is the dominant source of carbon emissions. However, there are major differences between these perspectives when looking at the end use sectors - buildings, industry, and transportation (Figure 3).

Currently the building sector accounts for $70 \%$ of all electricity consumption. At the point of use, there are no carbon emissions associated with electricity consumption. However, when one takes into account the primary energy used to generate the electricity and the losses inherent in energy conversion, transmission and distribution, the buildings sector is the demand sector most responsible for carbon emissions. The significance of this difference is that demand growth in this sector drives the need for new supply. From a systems perspective, tradeoffs involve balancing investments to increase the productivity of energy use with those made to develop new supplies.

Because energy is an enabler for virtually all human endeavors, developing robust energy solutions will require applying systems engineering that goes well beyond classic practices. Tools are need to enable examining security,

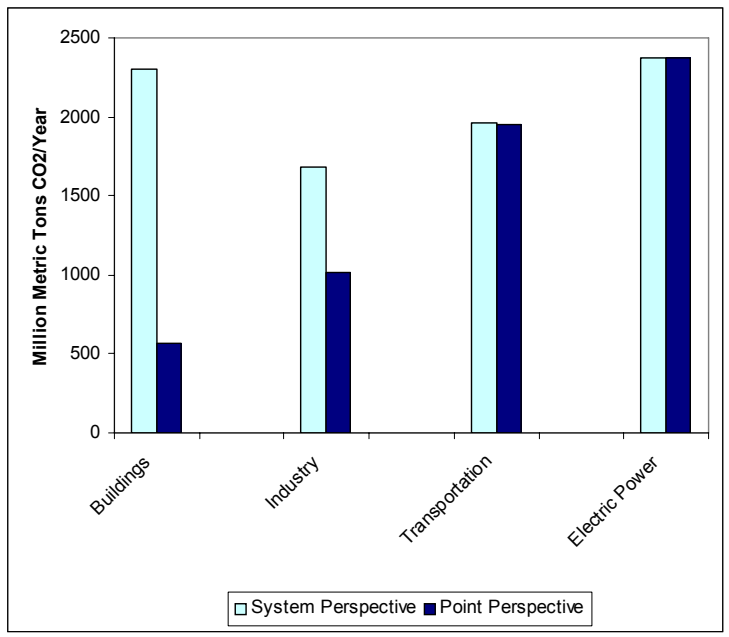

Figure 3. Carbon Emissions by Sector environment, growth and economic considerations on scales that range from local to global, and time periods that scale from fractions of seconds to centuries. For example, technology solutions to increase the reliability of the electricity grid need to consider phenomena that occur in nanoseconds whereas the impact of technologies adopted to mitigate global climate will play out over centuries.

Significant regional differences in energy use patterns, resources, infrastructure, public perceptions and other factors create the need for tailored technology solutions while at the same time addressing national goals. For example, electricity demand is expected to grow most rapidly in the West. Factors that are shaping how this new demand will be met include air quality standards, the availability of water, and capacity constraints in existing transmission and distribution infrastructure.

\section{A General Concept of Operations}

To meet the growing demand for energy without compromising security, environmental quality, or the ability to sustain economies, a significant transformation in the global energy enterprise is required over the coming decades. The capacity of the energy system will need to grow two to three fold by the end of the century. It is likely that a future energy system will need to include a greater diversity of supply, be capable of isolating and sustaining critical operations, and be capability of rapid repair and recovery to reduce concerns with security. A much more flexible and agile infrastructure for moving energy from source to use will be required to accommodate a diversity of resources that are geographically dispersed and the systems will need to be much more efficient in its use of energy in buildings, transportation, and industrial systems. The energy system will need to minimize its environmental footprint at the global and local levels, moving toward carbon-neutral technologies, minimizing its use of and impact on the quality of water, and minimizing and mitigating other emissions that affect local air, water, or land resources.

\section{The System Engineering Challenge}

Efforts to change energy infrastructure will require public and private sector commitment and investment over a multidecade period. Over this period, the operating envelope (e.g., markets and policy) will change and technology will advance. This will require that the assumptions made today regarding the concept of operations be revisited on a regular basis along with the technology options for meeting those requirements.

In considering the merits of various energy options, it is important to understand the key technical challenges that 
must be addressed, the timing in which the technology could be available, the potential for impact on the overall energy system if implemented at a material scale, and the impacts on the operating envelope. Public sector research and development programs use a variety of tools to assess the merits and consequences of alternative energy technologies. Among these are

- Market equilibrium models that project the market penetration of technologies over time assuming technical targets are met. These can be used to evaluate the potential timing and magnitude of impacts of new technologies.

- System models that evaluate the potential of individual components to contribute to the performance of the whole system. These are useful in identifying and targeting the areas where research could have the greatest impact on overall system performance.

- Life cycle analyses that identify the potential impacts, particularly environmental, of options over their useful life, from production/construction through operation and ultimately dismantling and disposal.

Increasingly, risk and uncertainty are being incorporated into the tools used to inform public energy research portfolio and policy decisions. Approaches to addressing risk and uncertainty include the use of expert judgment to identify and rank order technology and commercialization risks, use of scenarios to examine alternatives, and stochastic modeling.

\section{Transportation Options}

The U.S. is currently nearly $98 \%$ dependent on petroleum for transporting goods and people [3]. Most of this petroleum is purchased from foreign sources, with the nation's dependency on foreign imports slated to grow significantly over the coming years unless technology takes a different path. Continued reliance on petroleum raises concerns regarding the security of supply, the economic consequences of price volatility created by growing global demand and discontinuities in supply infrastructure, and it also comes at the cost of criteria pollutants (NOx, SOx) that affect local air quality and carbon emissions that affect the global environment.

Both near-term and longer term options for mitigating these impacts are available or under development. In broad terms, the benefits of investing in new technologies that fundamentally change the way that fuels are produced or consumed must be weighed against investments that can provide more immediate mitigation of potential disruptions. For example, there are significant tradeoffs implied in selecting among the following policy decisions: 1) increase the capacity of the Strategic Petroleum Reserve, 2) raise
CAFÉ standards, or 3) invest in research, development and demonstration efforts that will support transition to a hydrogen economy. Once policy vectors are established, the question of which technology options to pursue to implement those policies become at a fundamental level a choice between expanding the supply of alternative fuels or developing more efficient vehicles and transportation systems. Table 1 identifies some of the options available for fuel switching and vehicle efficiency. Clearly the supply and vehicle options are not independent of each other, nor are they independent of the electricity system. For example, a switch to plug-in electric vehicles would require developing higher density electric energy storage technologies along with the infrastructure to connect to the grid. Greater use of natural gas vehicles would require establishing delivery infrastructure and increasing demand would have an affect on the use of natural gas for electricity generation.

Transportation fuel switching options include alternative liquid fuels derived from abundant domestic resources, including coal, oil shale, and biomass; electricity; or, in the longer term, hydrogen. For many of these, significant technical challenges must be addressed to meet the system requirements. Among these challenges are developing:

Table 1. Transportation Petroleum Use Reduction Options

\begin{tabular}{|c|c|c|}
\hline System & Options & Technology Pathways \\
\hline \multirow{5}{*}{$\begin{array}{l}\text { Fuel Switching } \\
\text { Options }\end{array}$} & Natural Gas & \\
\hline & Biofuels & $\begin{array}{ll}\text { - } & \text { Ethanol } \\
\text { - } & \text { Biodiesel }\end{array}$ \\
\hline & $\begin{array}{l}\text { Alternative } \\
\text { Liquids }\end{array}$ & $\begin{array}{ll} & \text { Oil Shale } \\
\text { - } & \text { Coal Liquids }\end{array}$ \\
\hline & Electricity & $\begin{array}{ll}\text { - } & \text { Fossil } \\
\text { - } & \text { Renewable } \\
\text { - } & \text { Nuclear }\end{array}$ \\
\hline & Hydrogen & $\begin{array}{ll}\text { - } & \text { Fossil } \\
\text { - } & \text { Renewable } \\
\text { - } & \text { Nuclear }\end{array}$ \\
\hline \multirow[t]{3}{*}{$\begin{array}{l}\text { Vehicle } \\
\text { Efficiency } \\
\text { Options }\end{array}$} & Propulsion & $\begin{array}{ll}\cdot & \text { High-Efficiency } \\
& \text { Gasoline Engines } \\
\text { - } & \text { High-Efficiency } \\
& \text { Diesel } \\
\text { - } & \text { Battery } \\
\text { - } & \text { Fuel Cells } \\
\text { - } & \text { Hybrids }\end{array}$ \\
\hline & $\begin{array}{l}\text { Vehicle } \\
\text { Structure } \\
\text { (Weight } \\
\text { Reduction) } \\
\end{array}$ & $\begin{array}{ll}\cdot & \text { Size } \\
\text { - } & \text { Lightweight } \\
\text { Materials and } \\
\text { Structure } \\
\end{array}$ \\
\hline & $\begin{array}{l}\text { Vehicle } \\
\text { Systems }\end{array}$ & $\begin{array}{ll}\text { - } & \text { Auxiliary Load } \\
& \text { Reduction } \\
\text { - } & \text { Power Electronics } \\
\end{array}$ \\
\hline
\end{tabular}


- Effective and affordable carbon capture and sequestration technologies for all fossil resources,

- Producing biofuels cost effectively from sustainable resources (cellulosic materials, algae),

- Producing hydrogen and electricity from carbonneutral resources,

- High-density, cost effective storage systems for electricity and hydrogen.

The trade space among these alternative supply options includes, among other factors resource potential and location (domestic or foreign as well as proximity to market), time to market, cost, technical risk, environmental impact, materiality, and pubic acceptance. The time to market for oil shale or coal liquids is less than that of cellulosic ethanol and hydrogen. However, substantial use of these alternative fossil liquids before carbon sequestration technology is available will exacerbate the atmospheric carbon concentrations. On the other hand, accelerating the use of ethanol fuels, without advances in technologies to move beyond corn as the feedstock, will increase the competition for corn, drive up the cost, and impact other markets (food and feed). A major effort in China to develop ethanol production capacity led to that nation becoming the third largest producer. However, significant concerns with competition for water for growing crops for fuel versus food and the competition between fuel and food has required imposing limitations on ethanol development [4].

The typical trade space for vehicle systems involves cost, performance (power), and safety while also meeting mandated emissions requirements and fleet average fuel economy standards. Emerging options that have the opportunity to increase vehicle efficiency include: advances in propulsion technologies (such as highefficiency diesels, gasoline or fuel cell hybrids, and plug in hybrids), lightweight materials and structures, and/or technologies that reduce auxiliary loads.

The system interfaces between the vehicle and the fuel are extremely important considerations that become more complex as the number of fuels and vehicles types increases. System models such as ADVISOR (ADvanced VehIcle SimulatOR) enable simulation of conventional, hybrid, electric, or fuel cell vehicles over a variety of city or highway drive cycles to predict the vehicle performance (fuel economy, emissions, battery power, heat generated, and other measurements). These kinds of models are being used to help inform discussions regarding program goals and technical targets between the U.S. Department of Energy, the automotive industry, and energy companies.
The timeframe in which a significant change in oil consumption might be seen is highly dependent on when technology options will be available for market introduction, construction lead times for fuel production facilities, whether existing fuel delivery and fueling infrastructure can be used or new infrastructure must be developed, and how quickly on-the-road vehicles are replaced with new vehicles. As the Department of Energy establishes its research priorities, it considers these factors and uses models such as the National Energy Modeling System (NEMS) to examine alternative scenarios of how these technologies might enter the market place and what benefit might derive from their use.

\section{$5 \quad$ Electricity Options}

U.S. electricity consumption is projected to grow $1.5 \%$ annually, increasing more than $40 \%$ over the next 25 years [3]. In addition to fuel costs, some of the key factors that will drive the evolution of the nation's electricity generation and distribution system are expected carbon regulations, availability of water resources, reliability requirements, transmission and distribution system capacity constraints, and siting constraints driven by public perceptions. Table 2 summarizes some of the electricity system supply and end-use technology options.

A significant opportunity to impact the overall electricity system exists at the end use stage, particularly in the buildings sector which accounts for the most of the growth in electricity demand and the bulk of carbon emissions.

Table 2. Electricity Systems Options

\begin{tabular}{|c|c|c|}
\hline System & Options & Technology Pathways \\
\hline \multirow[t]{3}{*}{ Supply } & Coal & $\begin{array}{ll}\cdot & \text { Advanced } \\
& \text { Gasification } \\
- & \text { Carbon } \\
& \text { Sequestration } \\
\end{array}$ \\
\hline & Nuclear & $\begin{array}{ll}\text { - } & \text { Advanced Light } \\
\text { Water Reactor } \\
\text { - } & \text { High-Temperature } \\
& \text { Reactor } \\
\text { - } & \text { Closed Fuel Cycle } \\
\end{array}$ \\
\hline & Renewables & $\begin{array}{ll}\text { - } & \text { Wind } \\
\text { - } & \text { Solar } \\
& \text { Geothermal } \\
\end{array}$ \\
\hline \multirow[t]{2}{*}{ End Use } & Buildings & $\begin{array}{ll} & \text { Building Design } \\
\text { - } & \text { Advanced Lighting } \\
\text { - } & \text { Advanced } \\
& \text { Appliances }\end{array}$ \\
\hline & Industry & $\begin{array}{ll}\text { - } & \text { Efficient } \\
\text { Pumps/Motors } \\
\text { - Advanced } \\
\text { Processing }\end{array}$ \\
\hline
\end{tabular}


Every action to increase the productivity of energy use has a roughly three-fold impact on the productivity of the system due to the avoided conversion and transmission losses throughout the system.

In typical building design processes, trades are made between floor space and the quality of various amenities (windows, flooring, etc.) to design within cost constraints. Increasingly whole building energy design tools along with rating systems are helping designers and constructors consider energy and environmental implications throughout the design, construction, and commissioning process.

A key challenge in implementing efficiency technologies to reach a scale that has a material impact on the system is the number of informed individual investment decisions that must be made (e.g., individual homeowners or building owners). Because energy costs are not reflected in the first cost of buildings or equipment, making knowledge of downstream energy costs available to the consumer at the point of purchase has been a key role of government along with developing and implementing building and equipment codes and standards.

Among the research and development programs are major systems integration efforts such as the push toward net zero energy buildings. These designs would bring efficiency technologies together with building integrated power generation technologies in an operating system capable of providing comfort while at the same time producing as much energy as it consumes on annual basis. Other research is focused on advancing the next generation of components, materials, and equipment. For example, an accelerated research and development effort is underway to advance solid-state lighting (SSL). Based on breakthroughs in light-emitting diodes, SSL differs fundamentally from today's lighting technologies, driving the need for a systems perspective in how this new technology will integrate within the existing infrastructure and interact with other components.

Unlike transportation, electricity systems rely on a wider variety of primary energy resources, including coal, natural gas, nuclear, and a variety of renewable resources including hydro. In broad outline, the options and key technical challenges associated with the major electricity supply options include:

- Carbon-based fuels: Use of coal or biomass to produce heat for power generation will require effective and affordable carbon capture and sequestration technologies, near zero-emission combustion technologies, and advanced gasification. Growth in natural gas demand will require the infrastructure to support expanded imports of liquefied natural gas (LNG) will required addressing security issues and public perceptions regarding siting of LNG terminals.

- Nuclear generation: Advancing the nuclear options will requires addressing long-term storage of nuclear waste, developing proliferation resistant nuclear technology, closing the fuel cycle, and overcoming public perceptions to enable siting.

- Renewable generation: Using wind or solar for power production requires further development to improve the performance and reduce the cost of the technologies, system integration and control efforts to integrate the technologies with the grid or with the load, and ultimately impacting electricity production at scale will require developing cost-effective storage technologies.

To ensure reliable delivery of electricity to consumers, new technology must be introduced to modernize the aging and capacity constrained transmission and distribution system. At a general level, system options include central generation and delivery of electricity via T\&D lines, community-scale generation supported by micro-grids that can be connected to or islanded from the grid, and onsite generation connected to the load and operating in a grid-connected or standalone manner. Most likely, all three of these will be used within the future energy system making it necessary for the grid to be flexible and agile in terms of how it accommodates different operating paradigms.

Research and development to support higher reliability, efficient transmission and distribution of electricity is addressing:

- Next generation T\&D components, such as energy storage, high-temperature superconductivity, power electronics.

- System management tools such as real-time visualization, computational modeling, and monitoring technologies.

- Responsive load and integration technologies such as distributed generation interconnection technologies, micro-grids, sensors and real-time controls.

\section{Conclusions}

The scope and complexity of the energy system and its relationship to the dynamic and evolving envelope in which it will operate poses one of the most challenging and interesting systems engineering issues of the twenty-first century. Understanding the dynamics of the overall energy system and the tradeoffs associated with different technology options is critical to making informed policy and investment decisions. The transformation of energy infrastructure will occur over a multi-decade period during which time the operating envelope will change and advances in new technology will be made. The assumptions made today regarding the concept of operations will need to 
be revisited on a regular basis and technology options reassessed to meet changing requirements.

\section{References}

[1] Energy Information Administration. U.S. Department of Energy. "International Energy Outlook 2006". June 2006.

[2] Platts. Global Power Report. March 1, 2007. The McGraw-Hill Companies.

[3] Energy Information Administration. U.S Department of Energy. "Annual Energy Outlook 2007 with Projections to 2030 (Early Release)". December 2006.

[4] "Biofuels may not be the Ultimate Energy Panacea as Water Resources become Scare," Business Report (On Line). February 11, 2007. 


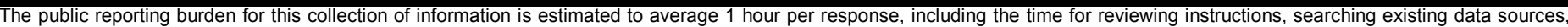

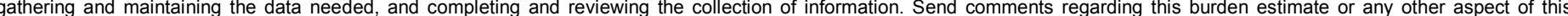

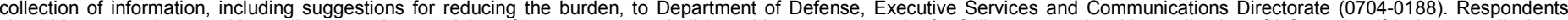

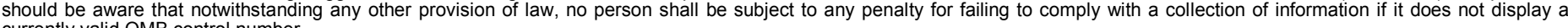
currently valid OMB control number.

PLEASE DO NOT RETURN YOUR FORM TO THE ABOVE ORGANIZATION.

\section{REPORT DATE (DD-MM-YYYY) April 2007}

4. TITLE AND SUBTITLE

Evolving the Nation's Energy Infrastructure: A Challenging System Issue for the Twenty-First Century: Preprint
3. DATES COVERED (From - To)

5a. CONTRACT NUMBER

DE-AC36-99-G010337

5b. GRANT NUMBER

5c. PROGRAM ELEMENT NUMBER

5d. PROJECT NUMBER

NREL/CP-600-41404

5e. TASK NUMBER

6001.1010

5f. WORK UNIT NUMBER

7. PERFORMING ORGANIZATION NAME(S) AND ADDRESS(ES)

National Renewable Energy Laboratory

1617 Cole Blvd.

8. PERFORMING ORGANIZATION

REPORT NUMBER

Golden, CO 80401-3393

NREL/CP-600-41404

9. SPONSORING/MONITORING AGENCY NAME(S) AND ADDRESS(ES)

10. SPONSOR/MONITOR'S ACRONYM(S) NREL

11. SPONSORING/MONITORING AGENCY REPORT NUMBER

\section{DISTRIBUTION AVAILABILITY STATEMENT}

National Technical Information Service

U.S. Department of Commerce

5285 Port Royal Road

Springfield, VA 22161

\section{SUPPLEMENTARY NOTES}

\section{ABSTRACT (Maximum 200 Words)}

Over the next several decades, a profound transformation of the global energy enterprise will occur driven largely by population growth and economic development. How this growing demand for energy is met poses one of the most complex and challenging issues of our time. The current national energy dialogue reflects the challenge in simultaneously considering the social, political, economic, and technical issues as the energy system is defined, technical targets are established, and programs and investments are implemented to meet those technical targets. This paper examines the general concepts and options for meeting this challenge.

\section{SUBJECT TERMS}

NREL; Bobi Garrett; Institute of Electrical and Electronics Engineers; energy systems; infrastructure; global demand; system of systems; system engineering; transportation; energy security; electricity; system management

\begin{tabular}{|c|c|c|c|c|}
\hline \multicolumn{3}{|c|}{ 16. SECURITY CLASSIFICATION OF: } & \multirow{2}{*}{$\begin{array}{l}\text { 17. LIMITATION } \\
\text { OF ABSTRACT } \\
\text { UL }\end{array}$} & \multirow{2}{*}{$\begin{array}{ll}\text { 18. } & \text { NUMBER } \\
& \text { OF PAGES }\end{array}$} \\
\hline $\begin{array}{l}\text { a. REPORT } \\
\text { Unclassified }\end{array}$ & $\begin{array}{l}\text { b. ABSTRACT } \\
\text { Unclassified }\end{array}$ & $\begin{array}{l}\text { c. THIS PAGE } \\
\text { Unclassified }\end{array}$ & & \\
\hline
\end{tabular}

\begin{tabular}{l} 
19a. NAME OF RESPONSIBLE PERSON \\
\hline 19b. TELEPONE NUMBER (Include area code) \\
\hline
\end{tabular}

